\title{
BIOCHEMICAL AND HISTOLOGICAL CHANGES IN THE LIVER OF DIOXIN (TCDD)- INTOXICATED
}

\section{RABBITS}

\author{
Mohamed, M. A. ${ }^{(1)}$; El-Alfy, Sh.H. ${ }^{(1)}$; Amer, Hager, E. ${ }^{(2)}$ \\ and Ibrahim, Somia, A. ${ }^{(2)}$ \\ 1) Zoology Department, Faculty of Science, Ain Shams University \\ 2) Biochemistry and Pathology units, Research Institute of Ophthalmology
}

\begin{abstract}
2,3,7,8- Tetrachlorodibenzo-p-dioxin (TCDD) is a highly persistent trace environmental contaminant that represents one of the most potent toxicants known to man. Dioxin is the name generally given to a class of super-toxic chemicals, formed as a by-product of the manufacture, molding, or burning of organic chemicals and plastics that contain chlorine. Oxidative stress may play a role in the toxic manifestations of dioxin. Therefore, the aim of this study was to investigate the dose-dependent effects of dioxin on various indices of oxidative stress along with other biochemical parameters in blood and liver of male rabbit, and to examine the histopathological consequences in the liver. Twenty four male rabbits were divided randomly into three groups. The first group (12 rabbits) served as control and vehicle-carrier. The other two groups, six rabbits each, received different oral doses of dioxin (3 and $6 \mu \mathrm{g} / \mathrm{kg}$ body weight) on seven consecutive days. Dioxin caused exaggerated oxidative stress response in dioxin-treated rabbits as indicated by significant changes in total antioxidant capacity, malondialdehyde (MDA), hydrogen peroxide $\left(\mathrm{H}_{2} \mathrm{O}_{2}\right)$, and reduced glutathione $(\mathrm{GSH})$ levels. Other biochemical parameters analyzed were also altered either slightly or significantly. The dioxin-mediated oxidative stress appears to cause hepatic histological changes. The hepatic tissue displayed microvesicular steatosis, and degenerative as well as necrotic changes. These changes were particularly prominent with the higher dose. In conclusion the results indicated that, the treatment of rabbits with dioxin may cause oxidative stress response and
\end{abstract}


changes in some biochemical parameters and hepatic histological architecture in a dose-dependent manner.

Key words: Tetrachlorodibenzo-p-dioxin; Oxidative stress; histology; liver.

\section{INTRODUCTION}

Dioxins are a group of chemically-related compounds which are persistent environmental organic pollutants. The most toxic compound is $2,3,7,8$ tetrachloro-dibenzo-p-dioxin (TCDD). Dioxins are the by products of various industrial processes and combustion activities, such as waste incineration and the burning of fossil fuels and rice straw (Deng et al., 2011; Minomo et al., 2011). They are found at low levels throughout the world in air, soil, water and sediment, and in foods such as dairy products, meats, fish and shellfish (Mohamed et al., 2015). The toxic effects of TCDD are known to be mediated by the aryl hydrocarbon receptor (AHR) (Bollati and Baccarelli, 2010), a cytosolic protein belonging to the basic- helix-loop-helix super family of transcription factors (Jones et al., 2004). Humans are primarily exposed to dioxins by eating food contaminated by these chemicals. Dioxins accumulate in the fatty tissue, where their half life in humans is estimated to be approximately 4 to 11 years (Lin and change, 2003). Dioxins can cause reproductive and developmental problems, damage to the immune system and obesity- related dysfunction. They are able to interfere with hormones and cause cancer (Yoshida and Ogawa, 2000). Also, dioxins are absorbed by passive diffusion and, therefore, they are rapidly distributed to tissues with high lipid content. In most animals studied, the major site of dioxin retention is the liver. Broad species variations were observed in metabolism and 
excretion (Theelen, 1991). Oxidative stress may play a role in the toxic manifestations of TCDD. Oxidative stress was first defined by (Sies, 1991) as "a disturbance in the oxidant to antioxidant balance in favor of the former, leading to potential damage". Oxidative stress can be defined as an excessive amount of reactive oxygen species (ROS), which is the net result of an imbalance between production and destruction of ROS. The relationship between TCDD tissue concentration and the corresponding oxidative stress response was not clearly defined. Therefore, the aim of this study was to investigate the dose-dependent effects of dioxin on various indices of oxidative stress in blood and liver of male rabbit and to examine the histopathological consequences in the liver.

\section{MATERIALS AND METHODS}

1.Chemicals: All chemicals were analytical grade. (2,3,7,8)tetrachlorodibenzo-p-dioxin (TCDD) 99\% purity) was purchased from Sigma-Aldrich, MO, USA. The stock solutions of $10 \mu \mathrm{g} / \mathrm{ml}$ were diluted with toluene acetone and corn oil (1:99) to prepare the dosing solutions. Kits for glucose test was purchased from Linear Chemicals, Spain. Kits for other biochemical assays were purchased from Biorex Diagnostics, UK and Biodiagnostic, Egypt.

2.Animals: Twenty four adult male New Zealand white rabbits weighing 1.8 to $2 \mathrm{Kg}$, of about three to four months old, were purchased and housed in the animal house of Research Institute of Ophthalmology, Egypt. They were housed under standard laboratory conditions at $25 \pm 2{ }^{\circ} \mathrm{C}$ and $12 \mathrm{hr}$ day/night cycle. The animals were allowed to acclimatize for two weeks before starting 
the experiments and were observed for general health. They were given free access to commercially available feed pellets and water ad libitum throughout the whole study. This study was approved and carried out in accordance with the ethical guidelines of the Faculty of Science, Ain Shams University, Egypt. 3.Experimental Design: After two weeks of acclimatization to standard laboratory conditions, twenty four adult male rabbits were randomly divided into three groups.

Group I was divided into two subgroups, subgroup Ia and subgroup Ib (six rabbits each) which served as control and vehicle-carrier, respectively.

Group II was the dioxin-treated group that included six rabbits received low dose of TCDD ( $3 \mu \mathrm{g} / \mathrm{kg}$ body weight) daily for one week by oral gavage.

Group III was the dioxin-treated group that included six rabbits received high dose of TCDD ( $6 \mu \mathrm{g} / \mathrm{kg}$ body weight $)$ daily for one week by oral gavage.

\subsection{Blood sampling and tissue homogenate preparation:}

At the end of experimental treatment, rabbits were kept fasting overnight and blood samples were then collected via cardiac puncture. Blood samples were collected from twenty four rabbits from each group and subgroup without anesthesia. Each blood sample was divided into two portions, one portion was heparinized and used for plasma separation and the other portion was used for separation of serum. Some heparinized blood samples were used for determination of hemoglobin concentration and reduced glutathione content. The remaining heparinized blood samples were centrifuged at 4,000 rpm for $15 \mathrm{~min}$ at $4{ }^{\circ} \mathrm{C}$ to separate plasma. Plasma samples were used for determination of glucose level and hydrogen peroxide concentration. Serum 
was separated by allowing blood samples to be clot for half an hour and then centrifuged at $4000 \mathrm{rpm}$ for $10 \mathrm{~min}$ at $4^{\circ} \mathrm{C}$. Serum samples were used for determination of AST, ALT, malondialdehyde and total antioxidant capacity.

All the animals were then sacrificed and dissected. Liver samples were excised and washed several times with ice-cold normal saline solution. One gram of liver samples was homogenized in $5 \mathrm{ml}$ of ice-cold phosphate buffer ( $\mathrm{pH} 7)$ using electric tissue homogenizer (Edmund Bühler GmbH, Germany). The homogenates were centrifuged at $4000 \mathrm{rpm}$ for $30 \mathrm{~min}$ at $4{ }^{\circ} \mathrm{C}$, and the supernatants were subsequently used for determination of concentrations of glutathione, hydrogen peroxide and malondialdehyde, and the total antioxidant capacity.

\subsection{Biochemical analyses}

\section{Determination of haemoglobin concentration:}

The blood haemoglobin concentration was determined by cyanomethehaemoglobin method according to the procedure described by Betke and Savelsberg (1950). The method is based on hemolysis of heparinized blood with Drabkin's solution containing potassium cyanide and potassium ferricyanide. The released haemoglobin is oxidized into cynmethemoglobin, whose color was measured spectrophotometrically at $540 \mathrm{~nm}$.

\section{Determination of reduced glutathione level:}

The reduced glutathione level was determined according to the method described by Beutler et al. (1963). The method is based on the reduction of 5,5'-Dithiobis (2-nitrobenzoic acid) with glutathione (GSH) to produce a chromagen. The reduced chromogen is directly proportional to GSH content, and its absorbance was measured at $405 \mathrm{~nm}$. 


\section{Determination of glucose level:}

Plasma glucose was determined enzymatically according to the method described by Yong (2000). In this method, the glucose is oxidized to Dgluconate by the glucose oxidase (GOD) with the formation of hydrogen peroxide. In the presence of peroxidase (POD), a mixture of phenol and 4aminoantipyrine (4-AAP) is oxidized by hydrogen peroxide to form a red quinoneimine dye proportional to the concentration of glucose in the sample.

\section{Determination of hydrogen peroxide concentration:}

Plasma hydrogen peroxide was determined colorimetrically according to the method described by Aebi (1984). In the presence of peroxidase, $\mathrm{H}_{2} \mathrm{O}_{2}$ reacts with 3,5- dichloro -2-hydroxybenzenesulfonic acid (DHBS) and 4aminoantipyrine (4-AAP) to form a chromagen, proportional to the concentration of hydrogen peroxide, which was monitored at $510 \mathrm{~nm}$.

\section{Determination of total antioxidant capacity:}

Total antioxidant capacity from serum was determined according to the method described by Koracevic and Koracevic (2001). The method is based on the reaction of antioxidants in the sample with hydrogen peroxide. The residual $\mathrm{H}_{2} \mathrm{O}_{2}$ was determined colorimetrically by an enzymatic reaction which involved the conversion of 3,5,dichloro-2 hydroxy benzene sulphonate to colored product which was monitored at $510 \mathrm{~nm}$. 


\section{Determination of malondialdehyde (MDA) content as a lipid}

\section{peroxidation marker:}

Malondialdehyde (MDA) was determined in blood serum according to Ohkawa et al. (1979). This method is based on the reaction of thiobarbituric acid (TBA) with MDA at $95{ }^{\circ} \mathrm{C}$ for $30 \mathrm{~min}$. The resultant product was measured at $530 \mathrm{~nm}$.

\section{Assessment of aspartate aminotransferase (AST) activity:}

The activity of AST in blood serum was measured using L-aspartate and $\alpha$-ketoglutarate and 2,4-dinitrophenylhydrazine according to Reitman and Frankel (1957). In this method, AST catalyzes the reversible transamination of L-aspartate and $\alpha$-ketoglutarate to oxaloacetate and L-glutamate. The oxaloacetate formed is then reacted with 2,4 dinitrophenylhydrazine to yield a colored hydrazone that can be measured at $546 \mathrm{~nm}$.

\section{Assessment of alanine aminotransferase (ALT) activity:}

The activity of ALT in blood serum was measured using L-alanine and $\alpha$ ketoglutarate and 2,4-dinitrophenylhydrazine according to Tietz (1976). In this method, ALT catalyzes the reversible transamination of L-alanine and $\alpha$ ketoglutarate to pyruvate and L-glutamate. The pyruvate formed is then reacted with 2,4-dinitrophenylhydrazine to yield a colored hydrazone that can be measured at $546 \mathrm{~nm}$.

\subsection{Histopathological examination:}

At the end of the experiments rabbits were sacrificed. The liver specimens were excised, washed with normal saline, fixed immediately in $10 \%$ neutral buffered formalin, dehydrated in graded series of ethyl alcohol, cleared in chloroform and were then embedded in paraplast. Five $\mu \mathrm{m}$-thick 
sections were cut using American Optical Rotary Microtome (AO-820, USA), stained with haematoxylin and eosin according to Bancroft and Gamble (2002), examined and photographed.

\subsection{Statistical Analysis:}

Data were assessed by one-way analysis of variance (ANOVA) and nonparametric test (Mann-Whitney U Test) to investigate between-group differences. The values were expressed as mean \pm SE. $\mathrm{P}$ values $<0.05$ were considered statistically significant.

\section{RESULTS}

\section{Biochemical changes:}

1.1.Analysis of blood: Mean values $\pm S E$ of Blood Glucose, Hemoglobin and serum AST \& ALT in control, low dose \& high dose rabbits exposed to dioxin are shown in Table (1).

As shown in Table (1). there was no significant changes in the level of blood glucose and hemoglobin in treated groups as compared to the control group. There was significant increase in the level of serum AST in treated groups as compared to the control group $(34.67 \pm 3.15,63.33 \pm 3.87,13.00 \pm$ $0.97 \mathrm{U} / \mathrm{L})$ respectively. Also, there was a significant increase in the level of serum ALT in treated groups as compared to the control group (48.17 \pm 2.63 , $79.67 \pm 2.79,22.00 \pm 1.15 \mathrm{U} / \mathrm{L})$ respectively.

As shown in Table (2). There was a significant reduction in the level of blood glutathione in treated groups as compared to the control group (15.10 $\pm 1.07,5.89 \pm 0.47,44.59 \pm 3.07 \mathrm{mg} / \mathrm{dl}$ ) respectively. A significant increase in the level of plasma hydrogen peroxide in treated groups as compared to the 
control group was also recorded $(0.47 \pm 0.07,0.65 \pm 0.02,0.13 \pm 0.02$ $\mathrm{mM} / \mathrm{ml}$ ) respectively. A significant increased in the level of serum malondialdhyde in treated groups as compared to the control group was also revealed $(5.32 \pm 0.33,9.10 \pm 0.77,3.18 \pm 0.14 \mathrm{nmol} / \mathrm{ml})$ respectively. A significant decrease in the level of serum total antioxidant was also recorded in treated groups as compared to the control group $(0.58 \pm 0.10,0.11 \pm 0.03$, $1.38 \pm 0.37 \mathrm{~m} \mathrm{M} / \mathrm{L})$ respectively.

\subsection{Analysis of Liver:}

The values demonstrated for liver reduced glutathione, hydrogen peroxide, malondialdehyde and total antioxidant in control, low dose and high dose of rabbits exposed to dioxin are shown in Table (3). As shown in this table there was a significant decrease in the liver glutathione and total antioxidant in treated groups as compared to the control group, However there was a significant increase in the liver hydrogen peroxide and malondialdehyde in treated groups as compared to the control group.

Table (1): Mean values \pm SE of blood glucose, hemoglobin and serum AST\&ALT in control, low dose $\&$ high dose rabbits exposed to dioxin.

\begin{tabular}{|c|c|c|c|c|c|}
\hline \multicolumn{2}{|c|}{ Groups } & \multirow{2}{*}{$\begin{array}{c}\begin{array}{c}\text { Glucose } \\
\mathrm{mg} / \mathrm{d} \mathrm{L}\end{array} \\
90.60 \pm \mathbf{5 . 2 6}\end{array}$} & \multirow{2}{*}{$\begin{array}{c}\begin{array}{c}\text { Hemoglobin } \\
\text { g/dl }\end{array} \\
\text { 13.8 } \pm 0.17\end{array}$} & \multirow{2}{*}{$\begin{array}{r}\begin{array}{c}\text { AST } \\
\text { U/L }\end{array} \\
13.00 \pm 0.97\end{array}$} & \multirow{2}{*}{$\begin{array}{c}\begin{array}{c}\text { ALT } \\
\text { U/L }\end{array} \\
22.00 \pm \mathbf{1 . 1 5}\end{array}$} \\
\hline $\begin{array}{l}\text { Group I } \\
\text { control }\end{array}$ & Mean \pm SE & & & & \\
\hline \multirow{2}{*}{$\begin{array}{l}\text { Group II } \\
\text { (Low } \\
\text { dose) } \\
\end{array}$} & Mean \pm SE & $110.27 \pm 5.55$ & $13.75 \pm 0.18$ & $34.67 \pm 3.15$ & $48.17 \pm 2.63$ \\
\hline & p-value & 0.06 & 0.04 & $0.004 * *$ & $0.004 * *$ \\
\hline \multirow{2}{*}{$\begin{array}{l}\text { Group } \\
\text { III (High } \\
\text { dose } \\
\end{array}$} & Mean \pm SE & $101.42 \pm 10.16$ & $14.57 \pm 0.28$ & $63.33 \pm 3.87$ & $79.67 \pm 2.79$ \\
\hline & P-value & 0.2 & 0.04 & 0.001* & 0.001* \\
\hline
\end{tabular}


Table (2): Mean values \pm SE of blood reduced glutathione, plasma hydrogen peroxide, serum malondialdhyde and total antioxidant in control, low dose $\&$ high dose of rabbits exposed to dioxin.

\begin{tabular}{|c|c|c|c|c|c|}
\hline \multicolumn{2}{|c|}{ Groups } & \multirow{2}{*}{$\begin{array}{c}\begin{array}{c}\text { Glutathione } \\
\text { mg/d L }\end{array} \\
\text { 44.59 } \pm 3.07\end{array}$} & \multirow{2}{*}{$\begin{array}{c}\begin{array}{c}\text { Hydrogen } \\
\text { peroxide } \\
\mathrm{mM} / \mathrm{ml}\end{array} \\
0.13 \pm 0.02\end{array}$} & \multirow{2}{*}{$\begin{array}{c}\begin{array}{c}\text { Malondialdhyde } \\
\text { nmol/ml }\end{array} \\
3.18 \pm 0.14\end{array}$} & \multirow{2}{*}{$\begin{array}{c}\begin{array}{c}\text { Total } \\
\text { antioxidant } \\
\text { mM/L }\end{array} \\
\mathbf{1 . 3 8} \pm \mathbf{0 . 3 7}\end{array}$} \\
\hline $\begin{array}{l}\text { Group I } \\
\text { (control) }\end{array}$ & Mean \pm SE & & & & \\
\hline \multirow{2}{*}{$\begin{array}{l}\text { Group II } \\
\text { (Low } \\
\text { dose) }\end{array}$} & Mean \pm SE & $15.10 \pm 1.07$ & $0.47 \pm 0.07$ & $5.32 \pm 0.33$ & $0.58 \pm 0.10$ \\
\hline & p-value & $0.001 * *$ & $0.001 * *$ & $0.001 * *$ & $0.004 * *$ \\
\hline \multirow{2}{*}{$\begin{array}{l}\text { Group III } \\
\text { (high } \\
\text { dose) }\end{array}$} & Mean \pm SE & $5.89 \pm 0.47$ & $0.65 \pm 0.02$ & $9.10 \pm 0.77$ & $0.11 \pm 0.03$ \\
\hline & P-value & $0.001 * *$ & $0.001 * *$ & $0.001 * *$ & $0.004 * *$ \\
\hline
\end{tabular}

$\mathrm{P}>0.05$ significant.

$\mathrm{P}<0.05$ non significant

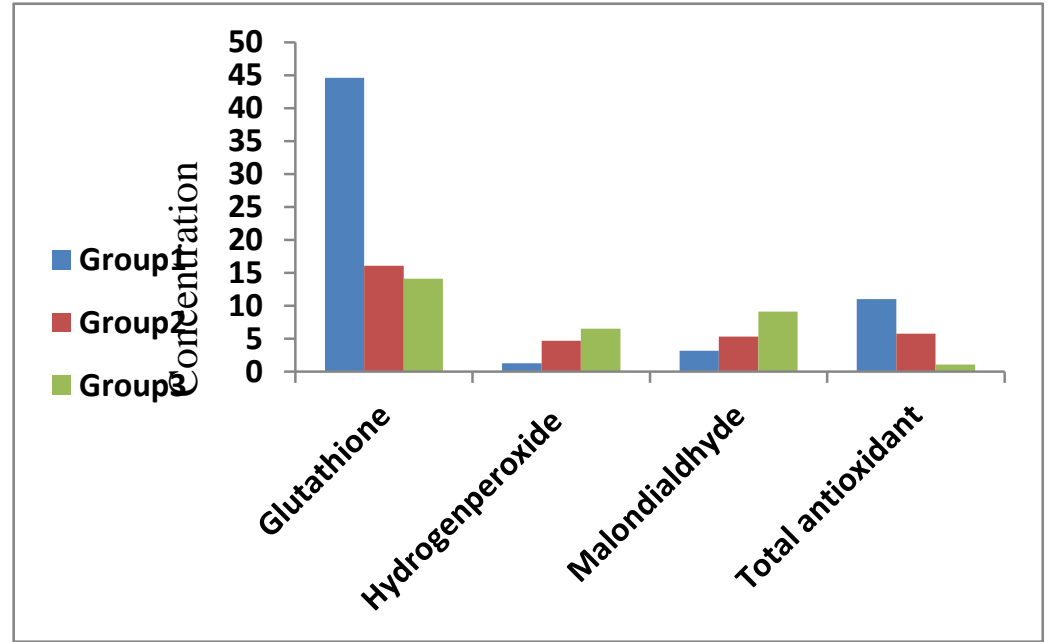

Fig.(2): Levels of blood reduced glutathione $\mathrm{mg} / \mathrm{d} \mathrm{L}$, plasma hydrogen peroxide $\mathrm{mM} / \mathrm{ml}$, serum malondialdehyde $\mathrm{nmol} / \mathrm{ml} \&$ Total antioxidant $\mathrm{mM} / \mathrm{L} \times 10$ in control and treated groups. 
Table (3): Mean values \pm SE \& of liver reduced glutathione, hydrogen peroxide, malondialdhyde and total antioxidant in control, low dose \& high dose of rabbits exposed to dioxin.

\begin{tabular}{|c|c|c|c|c|c|}
\hline & ups & $\begin{array}{l}\text { Glutathione } \\
\text { mg/g. tissue }\end{array}$ & $\begin{array}{l}\text { Hydrogen } \\
\text { peroxide } \\
\mathrm{mM} / \mathrm{g}\end{array}$ & $\begin{array}{l}\text { Malondialdhyde } \\
\text { nmol/g. tissue }\end{array}$ & $\begin{array}{c}\text { Total } \\
\text { antioxidant }\end{array}$ \\
\hline $\begin{array}{l}\begin{array}{l}\text { Group I } \\
\text { (control) }\end{array} \\
\end{array}$ & Mean \pm SE & $43.40 \pm 2.47$ & $0.17 \pm 0.02$ & $\mathbf{3 . 0 7} \pm \mathbf{0 . 0 8}$ & $1.14 \pm 0.08$ \\
\hline Group II & Mean \pm SE & $17.12 \pm 1.00$ & $0.43 \pm 0.02$ & $5.49 \pm 0.40$ & $0.51 \pm 0.05$ \\
\hline $\begin{array}{l}\text { (Low } \\
\text { dose) }\end{array}$ & p-value & $0.004 * *$ & $0.004 * *$ & $0.004 * *$ & $0.01 *$ \\
\hline Group & Mean \pm SE & $14.35 \pm 0.66$ & $0.60 \pm 0.02$ & $10.39 \pm 0.93$ & $0.52 \pm 0.03$ \\
\hline $\begin{array}{l}\text { III (HIIgh } \\
\text { dose) }\end{array}$ & P-value & 0.005* & 0.004* & 0.004* & 0.01* \\
\hline
\end{tabular}

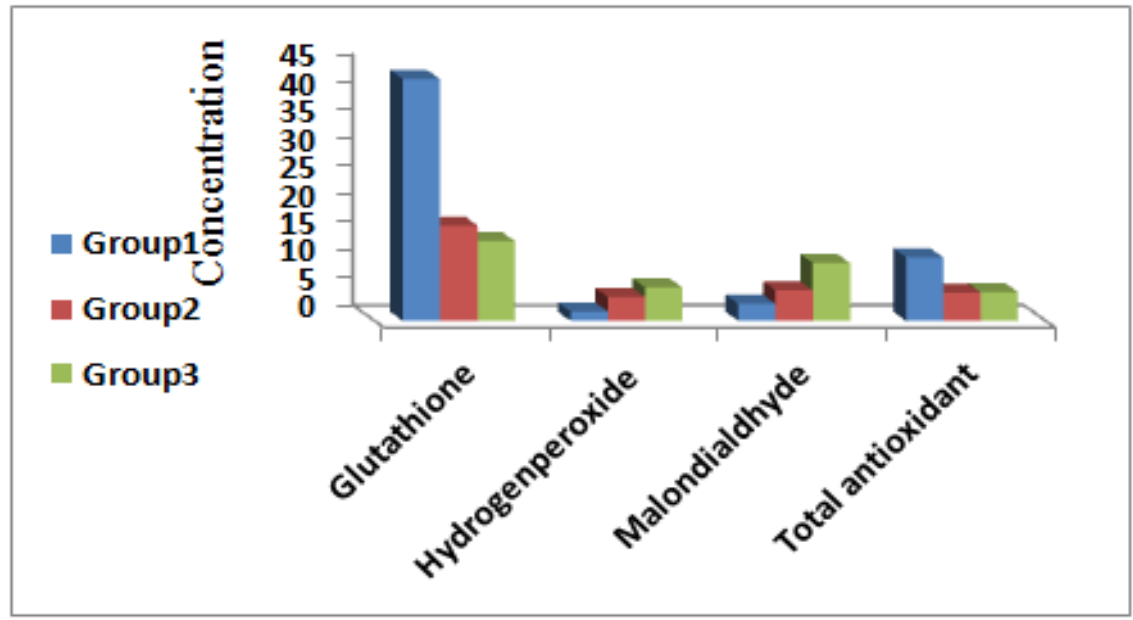

Fig.(3): Levels of liver reduced glutathione $\mathrm{mg} / \mathrm{g}$.tissue, liver hydrogen peroxide $\mathrm{mM} / \mathrm{g}$. tissue, liver malondialdehyde $\mathrm{nmol} / \mathrm{g}$. tissue $\&$ liver total antioxidant $\mathrm{mM} / \mathrm{g}$. tissue $\mathrm{x} 10 \mathrm{in}$ control and treated groups. 


\section{Histopathology}

Concerning the histopathological assessment of the effects of TCDD on the hepatic tissue of rabbits, the recorded microscopic findings in groups II and III were evaluated in reference to the control group, group I. Microscopic examination of the control hepatic tissue revealed hepatic lobules formed of a central vein surrounded by radially disposed hepatic strands. These strands anastomose forming a network with spaces forming the so-called liver sinusoids. The hepatic strands are made up of polyhedral hepatocytes with spherical centrally located nuclei. Binucleated cells were frequently observed. The hepatic lobules are separated from each other by interlobular connective tissue . At the periphery of hepatic lobules, the portal areas contain a cross section of each branch of portal vein, hepatic artery and bile duct. Rabbits given the toluene as a vehicle carrier also had normal liver architecture and organization (Fig.4A and B).

With regards to rabbits of group II, received low dose of TCDD, the hepatic tissue displayed almost preserved architecture. However, some hepatic lobules showed slightly congested sinusoids, but with normal size. Moderate damage of the sinusoidal endothelial cells was observed (Fig.5A and B). The central vein of few lobules appeared dilated and congested. Moderate microvesicular steatosis was seen in most hepatocytes (Fig. 5C). Moreover, The portal triads were slightly affected. Dilatation of the portal veins accompanied by sinusoidal congestion (Fig. 5D). 
In rabbits of group III, received high dose of TCDD, the hepatotoxicity was markedly evident. Loss of sinusoidal architecture and great dilation and congestion of central veins were observed. The hepatocytes revealed remarkable diffused macrovesicular steatosis and distorted nuclei (Fig. 6A and B). These changes were accompanied by severe hemorrhage. Hepatocytes of some hepatic lobules showed necrotic changes including substantial degeneration of cytoplasm and pyknosis or karyorrhexis or loss of nuclei (Fig. 6C and D). Marked dilation of portal veins and bile ducts accompanied by mononuclear infiltration were recognized in the portal tracts (Fig. 7A,B and C).
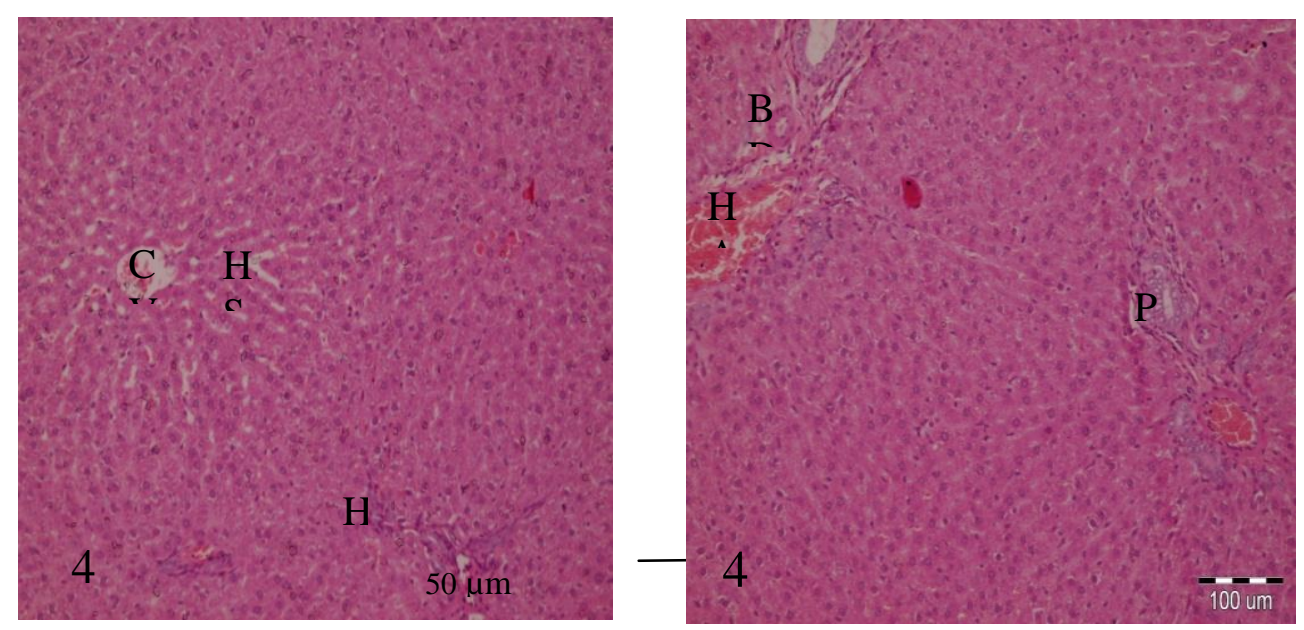

Fig.(4A and B). Photomicrographs of liver sections of a control rabbit showing the normal structure. (4A) Hepatic cords radiating from the central vein (CV) and hepatocytes $(\mathrm{H})$. The hepatic cords are separated by the hepatic sinusoids(HS). scale bar $=50 \mu \mathrm{m}$. (4B) The hepatic portal area containing a branch of the hepatic portal vein $(\mathrm{PV})$, branch of the hepatic artery (HA) and bile duct $(\mathrm{BD})$. H\&E, scale bar = $100 \mu \mathrm{m}$. 

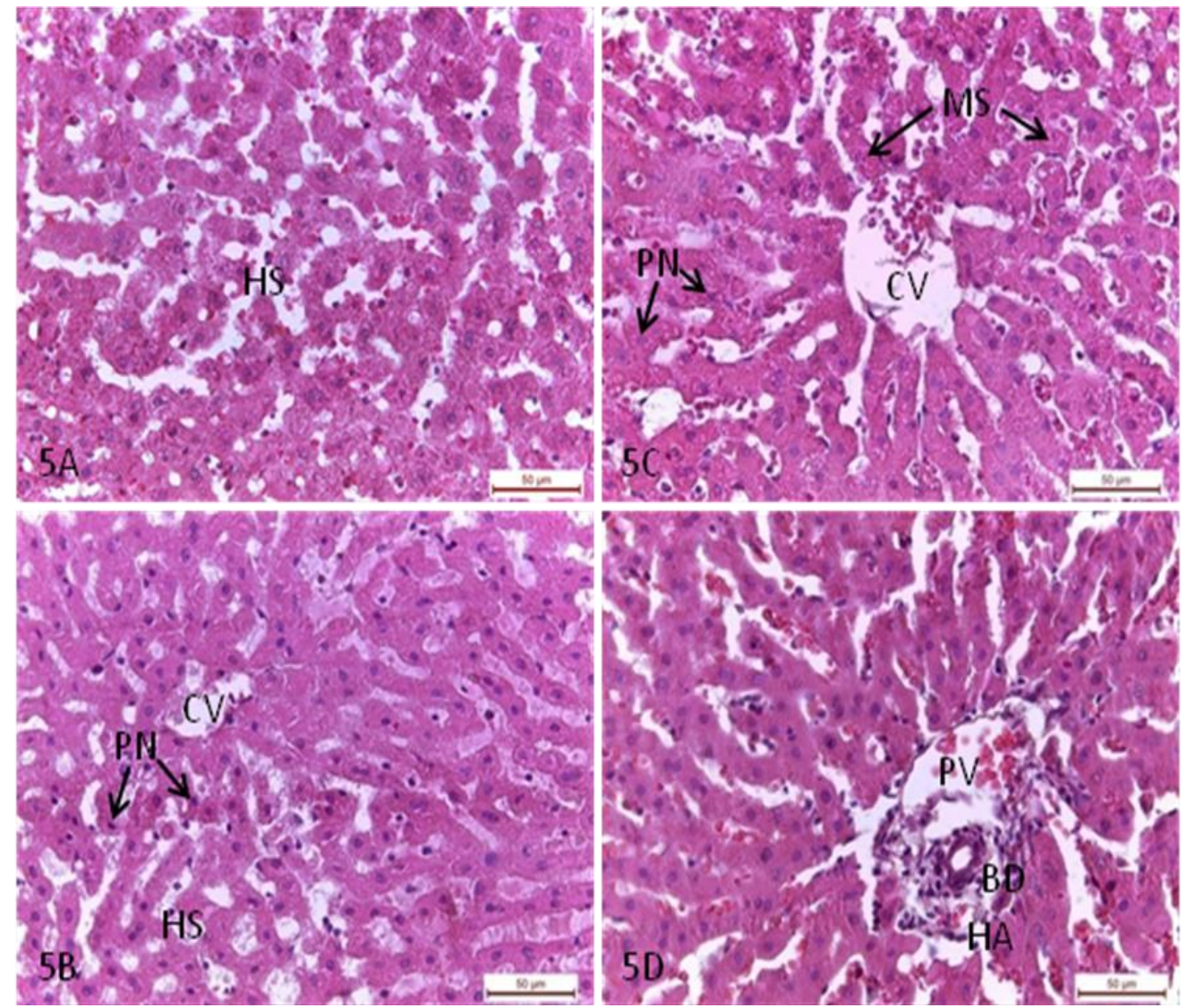

Fig (5). Photomicrographs of sections of the liver obtained from rabbits administrated with low dose of Dioxin. The liver parenchymal cells appear almost normal. (5A) Hepatic lobules show slightly congested sinusoids (HS). (5B) The central vein appears slightly dilated and congested (CV). (5C) Moderate microvesicular steatosis (MS) is seen in most hepatocytes. Portal triads almost maintain normal appearance. (5D) Slightly dilated portal vein (PV)and moderately congested sinusoids are noticed., branch of hepatic artery(HA) ; branch of bile $\operatorname{duct}(\mathrm{BD}) .(\mathrm{H} \& \mathrm{E}$, scale bar $=50 \mu \mathrm{m})$. 


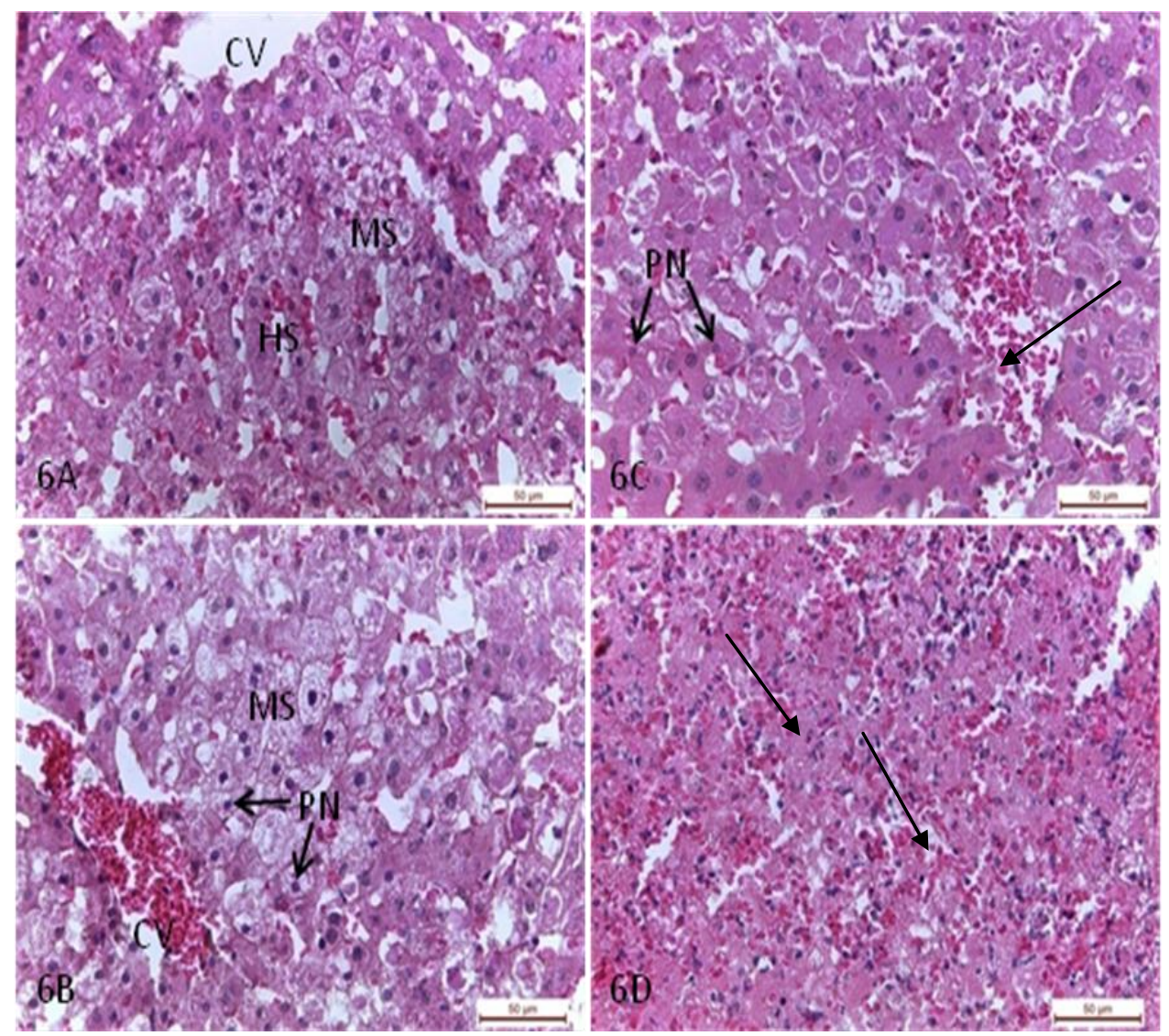

Fig (6). Photomicrographs of sections of the liver obtained from rabbits administrated with high dose of Dioxin. The liver parenchymal cells lose their normal architecture. (6A and B)The central vein (CV) appears highly dilated and congested. Hepatic lobules show highly congested sinusoids (HS). Macrovesicular steatosis (MS) is evident accompanied by distorted nuclei. (6C) Severe hemorrhage is observed(arrow). Hepatocytes display necrotic changes including substantial degeneration of cytoplasm and pyknosis (PN). (6D) Some hepatocytes lose their nuclei (arrow). ( H\&E, scale bar $=50 \mu \mathrm{m})$. 

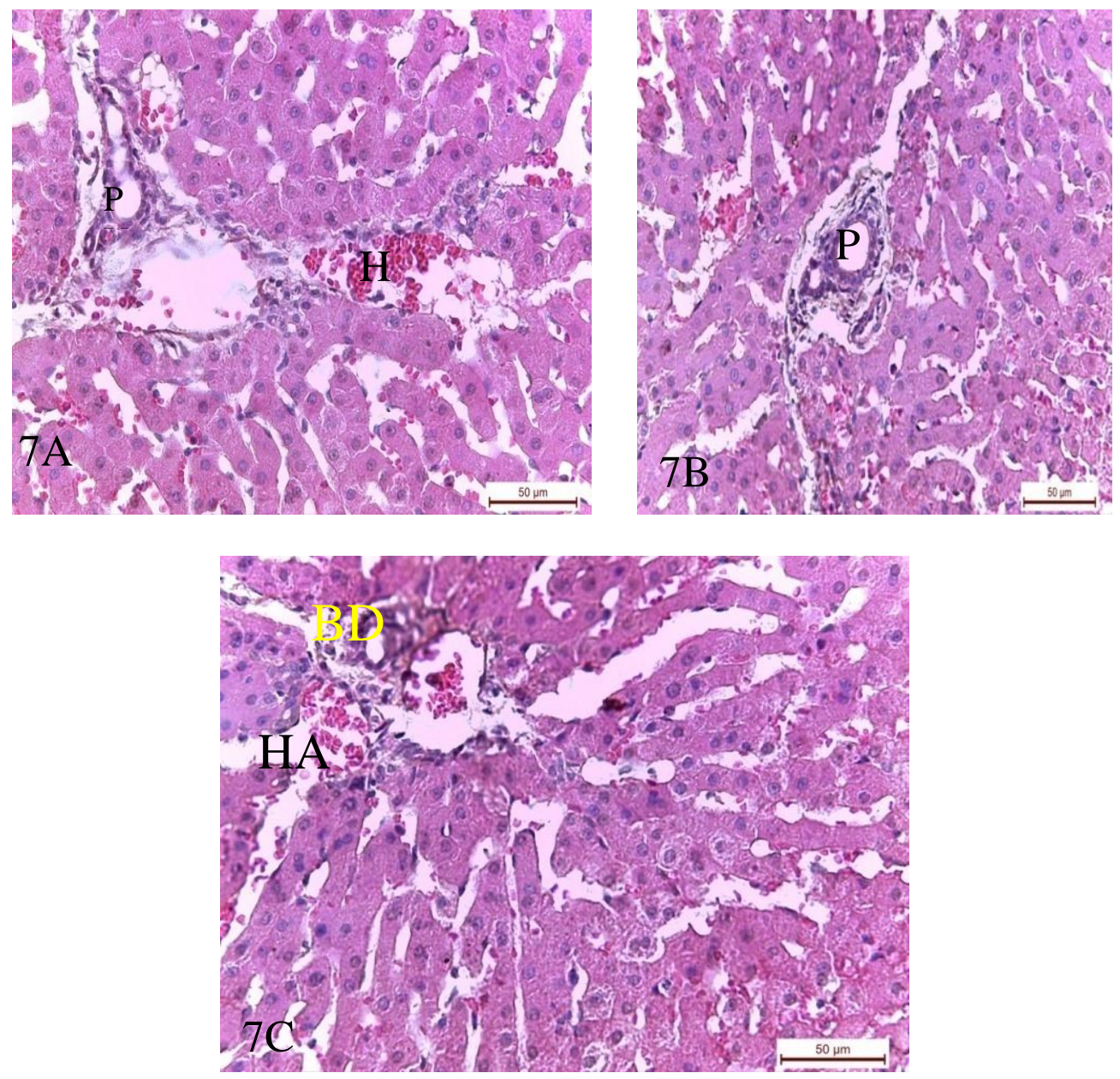

Fig (7). Photomicrographs of sections of the liver obtained from rabbits administrated with high dose of dioxin. Portal triads almost maintain the normal appearance. (7A) Slightly dilated portal vein (PV) and moderately congested sinusoids are noticed (HS). (7B and C) Marked dilated in Branch of portal vein (PV); branch of hepatic artery(HA) ; branch of bile duct (BD) accompanied by mononuclear infiltrate. $(\mathrm{H} \& \mathrm{E}$, scale bar $=50 \mu \mathrm{m})$. 


\section{DISCUSSION}

2,3,7,8-Tetrachlorodibenzo-p-dioxin(TCDD) is among persistent aromatic hydrocarbons in the environment and has been shown to displays wide spectrum of toxic effects, including dermal toxicity, immunotoxicity ,hepatotoxicity, carcinogenesis,, neurobehavioral, endocrine and metabolic alterations abnormalities in humans (Hung et al., 2006). Reactive oxygen species are produced in response to exposure to environmental toxins, such as TCDD (Stohs, 1990). The generation of reactive oxygen species can lead to oxidative stress, cell damage and disease. A hallmark of oxidative stress is lipid peroxidation, which disrupts the structural integrity of cell membranes and can also lead to the formation of aldehydes, which in turn further damage lipids, protein, and DNA. Cells possess defense mechanisms to protect against free radical damage including enzymes such as superoxide dismutase, which scavenger free radicals to form non- radical products. Two other keys 'antioxidant' enzymes are catalase and glutathione peroxidase, both of which decompose peroxides. Most animal studies on TCDD effects are concerned with chronic administration of this substance. For this reason, in our study we have chosen to administer TCDD in low and high doses for shorter time. Moreover, the present study was also designed to examine the effects of TCDD on markers of oxidative stress and histological changes in liver of rabbit.

There was no significant changes in blood glucose in rabbits treated with low and high dose of TCDD. These results are in agreement with (Warner et al., 2013). They found no association of serum TCDD levels with diabetes. Our finding is not consistent with previous prospective studies that reported a 
positive association between TCDD exposure and diabetes (Consonni et al., 2008). There was no significant change in blood haemoglobin in treated groups, which means that rabbits don't suffer from anemia or that no interference occurs with haemoglobin synthesis.

The changes in liver function tests (serum ALT \& AST) observed in our study were must likely caused by hepatic damage. This observation is consistent with other studies on the TCDD effects in rats (Ohbayashi et al., 2007 and Salim et al., 2013). Elevation of liver enzymes is used as marker of liver injury due to their leakage from damaged cells (Giannini et al., 2005). This is particularly clear in the comparison of the treated groups and the control group. The damage is proportional to TCDD dose.

The present study revealed a significant decrease in GSH level in blood and liver in treated groups as compared to control. A decline in GSH level has been considered to be indicative of oxidative stress, since glutathione plays a significant role in the detoxification of xenobiotics and maintenance of the redox status of the cell. These results are in line with (Pohjanvirta et al., 1990) who found a decrease in glutathione content of liver in TCDD treated rats. On the contrary, Shen et al. (2012) reported an increase in the levels of GSH and GSSG in both cytosol and mitochondria in mouse liver given TCDD.

The present study showed significant increase in the level of serum and liver malondialdehyde in treated groups as compared to the control. The observed alterations may be the result of increased production of free radicals and depletion of the antioxidant defense system. This compound is the 
breakdown product of the major chain reactions leading to the oxidation of polyunsaturated fatty acids and thus serves as a marker of oxidative stress in the body (Bhadauria et al., 2007). The marked increase in LPO in liver microsomes may be due to the increase in the production of $\mathrm{H}_{2} \mathrm{O}_{2}$ or decrease in the activities of the antioxidant enzymes and thiol contents (Jin et al., 2008). It was reported that TCDD reduced the ability to scavenge ROS and thus contributes to oxidative stress (Ciftci et al., 2011).

The current study showed a significant increase in the level of $\mathrm{H}_{2} \mathrm{O}_{2}$ in plasma and liver in treated groups. These results are in agreement with previous studies which showed that environmental contaminant of TCDD increases the succinate dependent mitochondrial production of superoxide and hydrogen peroxide (Senft, et al., 2002).

In the present study, TAC as an important parameter was used to monitor the development and extent of liver damage due to oxidative stress. It was observed that TAC is significantly lowered in serum and liver in treated groups. As known, TAC comes from non-enzymes like glutathione, as well as enzymes such as superoxide dismutase, catalase and glutathione peroxidase (Murri et al., 2010).

Histological assessment revealed hepatic damage in groups of rabbits exposure to dioxin. The present study showed that rabbits received low oral dose of TCDD, the hepatic tissue displayed preserved architecture with moderate diffuse hepatic damage as well as diffuse microvascular type, signs of early piece metal necrosis., scattered hepatocytes, swollen cells with hydropic changes, and inflammatory cell infiltrate. Several studies were in accordance with the present results. Yang et al. (2005) reported that TCDD 
caused liver damage with hepatocytes hydropic changes, necrosis, inflammatory cell infiltration and increase in relative liver weights. Also histopathological examination carried by Fouzy et al. (2007) showed degenerative and necrotic changes associated with inflammatory reaction in liver and kidney. They added, liver displayed diffuse granular and vascular degeneration with the hepatic cells appeared markedly swollen with finely granulated and vacuolated cytoplasm and thickening of the cell membrane in goats exposed to TCDD.

In addition, histological examination of liver of rabbits received high oral dose of TCDD revealed hepatotoxicity that markedly evident in the form of sever diffuse microvesicular steatosis, evident vascular dilatation and dense lymphocytic infiltrate with piece meal necrosis, with sinusoidal changes. A recent study by Aydino et al. (2014) reported that, in histopathological studies of livers of TCDD treated rats slight degeneration and enlargement of sinusoidal spaces with increase number of mitotic figures and mutinucleation are seen. He also concluded that either single or repeated exposures to TCDD caused liver damage with hepatocyte hydropic changes, necrosis, and inflammatory cell infiltration. Also, Jacek et al. (2009) reported that rats received a high dose of dioxin hepatic lobules revealed parenchymal degeneration and vacuolization of hepatocytes, and inflammatory infiltration surrounding hepatocytes. AbdEl-Fattah et al. (2013) found that, TCDD caused basophilic hyper chromatic nuclei, hepatic degeneration and fibrosis in rats liver. In addition, histological examination of liver of rabbits received high oral dose of TCDD, the portal triad was also affected in the form of 
widening with vascular dilatation. This may indicate the toxic effect of TCDD in dose-dependent manner.

In conclusion, our study revealed that exposure to TCDD induced increased production of reactive oxygen species which lead to increased oxidative stress in liver. However, the imbalance between reactive oxygen species production associated with TCDD exposure, and the antioxidant defense capacity may lead to oxidative stress, with consequent increased consumption of antioxidants and accumulation of toxic compounds in liver. Light microscopic assessment provided structural functional changes in liver of rabbits after exposure to TCDD.

Recommendation, Thus we recommended that human must be avoidance of exposure to dioxin needs to be the first line of public health protection. Also, human works in area polluted with dioxin must be increased consumption of fruits and vegetables or certain dietary supplements can substantially enhance the protection against many common types of environmental induced oxidative stress such as dioxin.

\section{REFERENCES}

Abd El- Fattah., Hanaa M., Abdel- Kader Z.M., Hassnin E.A., Mohamed K. Abdel-Rahman and Lamiaa E. Hassan(2013).Toxicology and food technology., 7: 11-17.

Aebi H. (1984). Determination of hydrogen peroxide concentration by colorimetric. Methods Enzymal., 105:121-126.

Aydino, Akyuzf, N. Tekin, D. burukoglu, H. Ozden, C.M. ustuner and I. Degirmenci (2014). The role of retinyl acetate in Chemoprevention. Jornal of Food and Nutration Research.,2-1: 916. 
Bancroft j. D. and Gamble M. (2002). Theory and practice of Histological techniques. $5^{\text {th }}$. Ed. Edinburgh. Churchill livingstone pub.,172 - 5, 593- 620.

Betk K. and Savelsberg W.(1950). Stufenphotometrische Hämoglobin bestimmung mittels Cyanhämiglobin. Biochem Z., 320(5):43143.

Beutler E., Duren o. and Kelly AB. (1963).Determination of glutathione reduced concentration by colorimetric method. ,J Lab. Clin. Med.,61,882.

Bollati V: and Baccarelli A. (2010). Environmental epigenetics. Heredity (Edinb)., 105(1):105-12.

Bhadauria M., Nirala S. K. and Shukla S.(2007). Hepato - protective efficacy of propolis extract: A biochemical and histopathological approach Iranian. Journal of Pharmacology and Therapeutics., 6: 145-154.

Ciftci O., Ozdemir I., Tanyildizi S., Yildiz S. and Oguzturk H. (2011). Antioxidative effects of curcumin, $\{$ beta $\}$-myrcene and 1,8cineole against 2,3,7,8-tetrachlorodibenzo-p-dioxin-induced oxidative stress in rats liver. Toxicology and Industrial Health., 27: 447-453.

Consonni D., Pesatori AC., Zocchetti C., Sindaco R., D’Oro LC. And Rubagotti M.(2008). Mortality in a population exposed to dioxin after the Seveso, Italy, accident in 1976: 25 years of followup. Am J Epidemiol., 167:847-858.

Deng, P-Peng, M-Ren, J-Song and W-Huang. (2011). The winter effect on formation of PCDD/Fs in Guangzhou by vehicles: A tunnel study. Atmospheric Environment. 45,(15):2541-2548.

Fouzy A.S.M, Desouky H.M , Ghazi Y.A. and Hammam A.M (2007). Some clinico and histopathological changes in female experimentally exposed to dioxin Pakistan. Journal of Biological Sciences., 10:1213-1220.

Giannini E., Roberto T., and Vincenzo S.(2005). Liver enzyme alteration : a guide for clinicians. Can Med Associa J., 172,367-79. 
Hung Y., Huang GS., Sava V.M., Blagodar sky V.A. and Hong M.(2006). Protective effects of tea Melanin against 2,3,7,8Tetrachlorodibenzo-P dioxin-Induced toxicity: Antioxidant activity and aryl hydrocarbon receptor suppvessine effect. Biological \& Pharmaceutical Bulletin.,29(11): 2284-2291.

Jacek Czepiel, Grazyna Biesiada, Marius Z. Gay DA., Wojciech Szczepanski, Kinga Szypula, Zbigniew Dabrowski, and Tomasz Mach.(2009). The effect of TCDD dioxin on the rat liver in biochemical and histological assessment. Folia Biologica (Krakow)., 58, no(1-1),85-90(6).

Jin MH., Hong CH., Lee HY., Kang HJ., and Han SW. (2008). Enhanced TGF-b1 is involved in 2,3,7,8-tetrachlorodibenzo-p-dioxin (TCDD) induced oxidative stress in C57BL/6 mouse testis. Toxicological Letters., 178: 202-209.

Jones JM., Morrell JC. And Goulds J.(2004). P EX 19 is a predominatly cytosolic chaperone and import receptor for class 1 peroxisomal membrane proteins. J Cell Biol., 5,164(1):57-67.

Koracevic D. and koracevic G., (2001).Determination of Total Antioxidant capacity by colorimetric method. Clin. Pathol., 54,356 - 361 .

Lin P., S. W., Hu and T.H., Change.(2003). Correlation between gene expression of aryl hydrocarbon receptor (AhR), hydrocarbon receptor nuclear translocator (Arnt), cytochromes P4501A1 ( CYP1A1) and 1B1 (CYP1B ) and inducibility of CYP1A1 and CYP1B1 in human lymphocytes. Toxicological Science., $71: 20$ $-26$.

Minomo K., ohtsuka N., Nojiri k., Hosonos and kawamura k. (2011). Polychlorinated dibenzo - P- dioxins, dibenzofurans and dioxim like polychlorimated biphenyls in rice straw smoke and their origims in japan. Chemosphere., 84: 950-956.

Mohamed SA., El-Gerbed, Ahmed.M., AbuEL-saad and Abdullah Bedeer Haussein (2015). 2,3,7,8-Tetrachloro-dibenzo-P-dioxin induced testicular toxicity in rats and the protective effect of quercetin: Biochemical, histopathological and immune histochemical 
studies. Journal of Applied Pharmaceutical Science., 5(1): 099109.

Murri M., Garcia-Delgado R., Alcázar-Ramirez J., Linde F., FernándezRamos A., Cardona F. and Tinahones FJ(2010). Assessment of cellular and plasma oxidative stress in SAHS patients before and after continuous positive airway pressure treatment. Clinical Laboratory., 56:397-406.

Ohbayashi H., Sasaki T., Magano K., Noguchi T., Yamazaki K., Aiso S., Nagano K., Arito H. and Yamamoto.(2007). Dose- and timedependant effects of 2,3,7,8-tetrachlorobenzo-p- dioxin on rat liver. J. Toxicol. Sci., 32:47-56.

Ohkawa H., ohishi w. and Yagi k. (1979). Determination of Lipid peroxide (Malondialdehyde) concentration by colorimetric method., Anal. Biochem., 95,351.

Pohjanvirta R1., Sankari S., Kulju T., Naukkarinen A., Ylinen M. and Tuomisto J. (1990). Studies on the role of lipid peroxidation in the acute toxicity of TCDD in rats. Pharmacol Toxico., 66(5):399408.

Reitman S. and Frankel S.(1957).Determination of AST concentration by colorimetric (Table). American Journal of Clinical Pathology., 25 $: 56$.

Salim A., Zohair A., and Abou-Arab A.A.K.(2013). Protective effect of Turmeric on 2,3,7,8- tetrachlorodibenzo-p- dioxin induced oxidative stress and hepatotoxicity in rats. Journal of Applied Sciences Research., 9(3): 1790- 1797.

Shen X. L., Jia L. H., Zhao P., et al.(2012). Changes in blood oxidative and antioxidant parameters in a group of chinese patients with agerelated macular degeneration. Journal of Nutrition, Health and Aging., 16(3):201-204.

-Sies H (1991). Oxidative stress: introduction. In: Sies H., editor. Oxidative stress: oxidants and antioxidants. Academic Press; London: pp. xv-xxii. 
Senft AP., Dalton Tp. Nebert DW., Genta MB., puga A., Hutchinson RJ., Kerzee jk , unos And shertzer HG. (2002).Mitochondrial reactive oxygen production is dependent on the aromatic hydrocarbon receptor free Radic. Biol. Med., 33 : 1268 - 1278.

Stohs S.J. (1990,).Polychlorinated biphenyls (PCBs),dibenzo-p-dioxins (PCDDs), dibenzofurans (PCDFs), and related compounds: environmental and mechanistic considerations which support the development of toxic equivalency factors (TEFs) Crit. Rev Toxicol., 21:51-88.

Theelen, R. M. C. (1991). Modeling of human exposure to TCDD and I-TEQ in the Netherlands: Background and occupational. In Banbury Report 35: Biological basis for risk assessment of dioxins and related compounds, eds. M. A. Gallo, R. J. Scheuplein and K. A. van der Heijden., 277-290. Cold Spring Harbor, NY: Cold Spring Harbor Laboratory Press.

Tietz N.W. (1976). Determination of ALT concentration by colorimetric. Endpoint - Fundamentals of clinical chemistry W.B. saunders co., Philadelphia., 682.

Warner M., Mocarelli P., Brambilla P., Amelia Wesselink A., Samuels S., Signorini s., and Eskenazi B.(2013). Diabetes, metabolic syndrome, and obesity in relation to serum dioxin concentrations: The Seveso Women's Health Study. Environ Health Perspect., 121(8): 906-911.

Yang, Dong-Yang Huang, Liu, Chang Zhong, and Hong Song.(2005). Inhibitory effects of vitamin A on TCDD-induced cytochrome p$4501 \mathrm{~A} 1$ enzyme avtivity and expression. Toxicological sciences., 85.727-734.

Yong.(2000). Effects of drugs on clinical laboratory tests. Fifth Edition, AACC press, Manufactured by thermo Fisher Scientific clinical., 46:53-55.

Yoshida, R., and Ogawa,Y.(2000). oxidative stress induced by 2,3,7,8 tetrachlorodibenzo - P - dioxin: An application of Oxidative stress Markers to cancer Risk Assessment to dioxins. Ind Health., 38(1):5-14. 


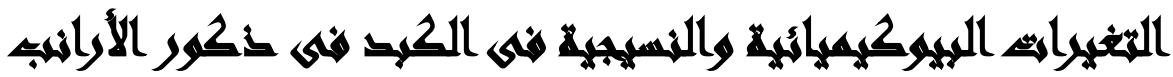

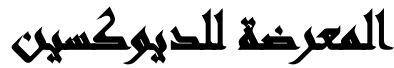

[1]

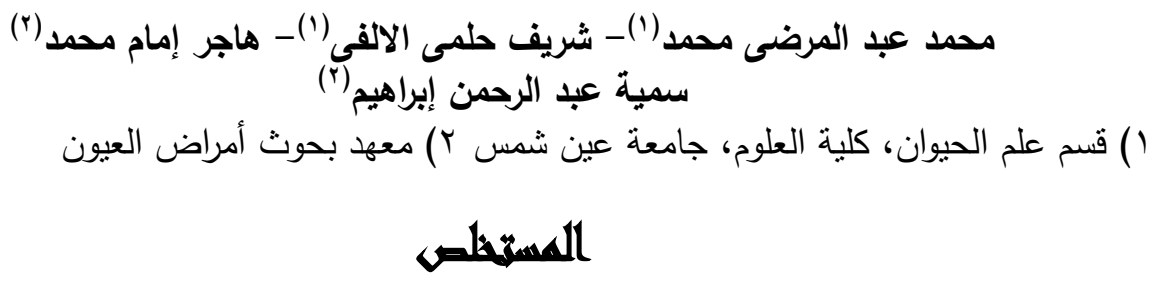

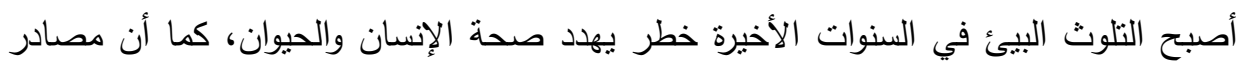

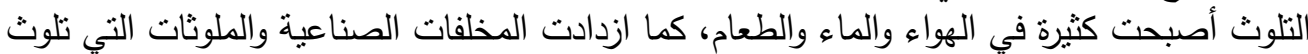

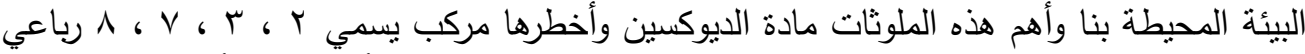

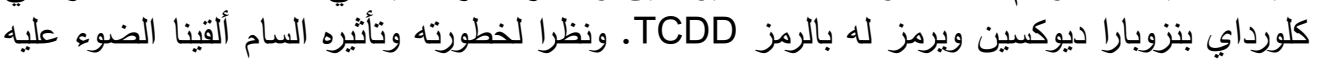

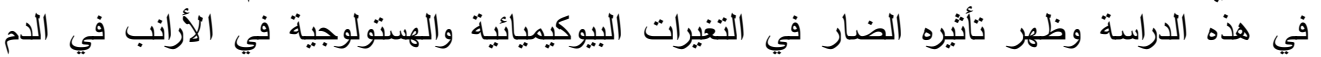

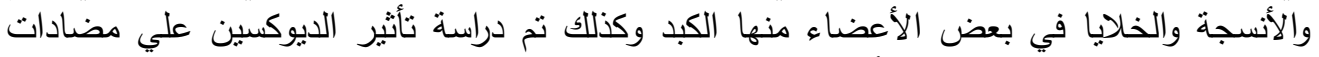

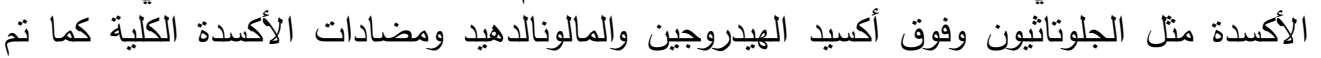

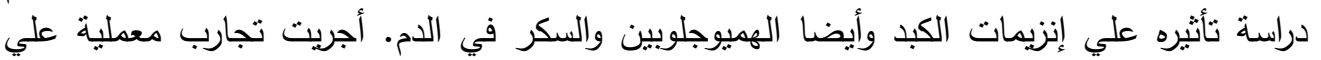
ذكور الأرانب وأعطيت الجرعة عن طريق الفم بالثرب واستخدمنا الجرعة المنخفضة وكانت

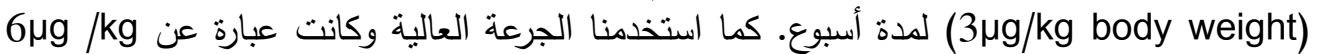

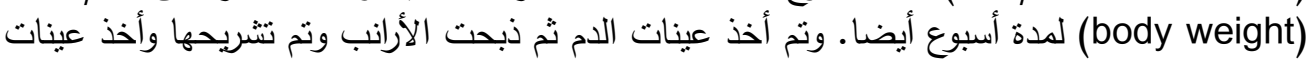

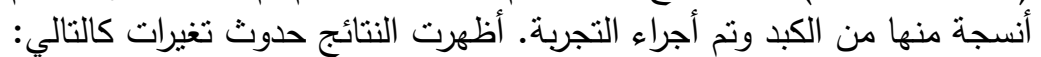

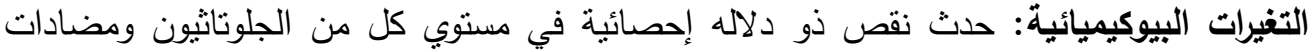
الأكسدة الكلية. زيادة ذات دلاله إحصائية في مستوي إنزيمات الكيات الكبد ALT, AST.

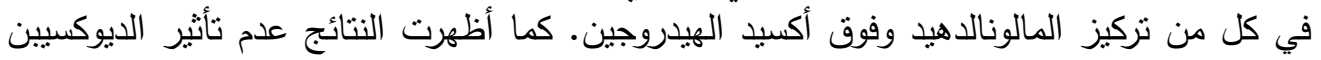

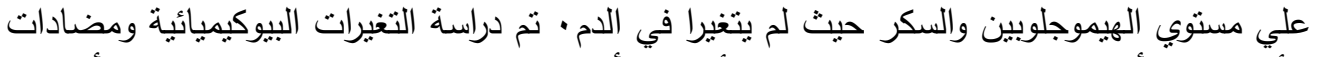

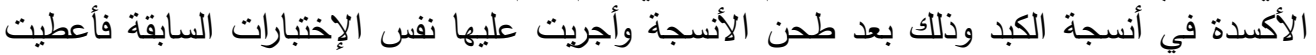

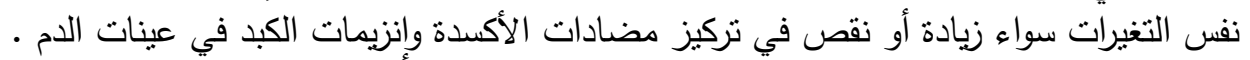

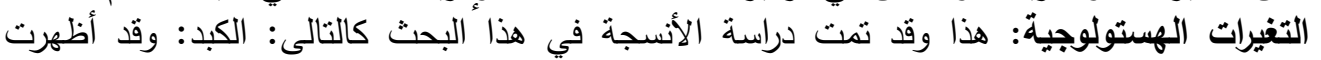

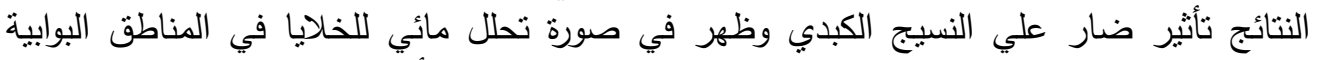

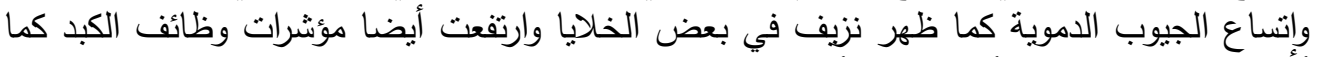
أُشُنا من قبل. ولاحظنا أن معدل التأثنير للمعايير السابقة جميعا كان واضحا جدا في المجموعات التي وناتي 
تعرضت للايوكسين لمدة أسبوع سواء من الجرعة المنخفضة أو الجرعة العالية بالمقارنة بمجموعة

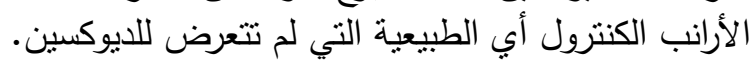
وتوصي الدراسة بعدم التعرض لتلك المركبات الملوثة خاصة لإئة الديوكسين والبعد عن أماكن

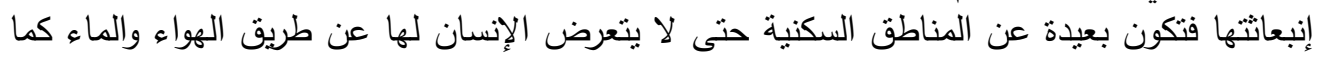

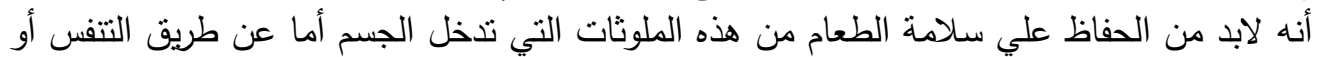

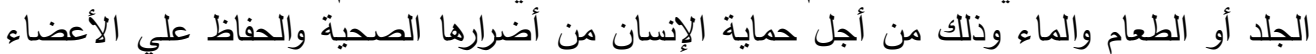
سليمة وهي نعمه كبيرة من الله سبحانه وتعالي فلنحافظ عليها والحمد لله. 